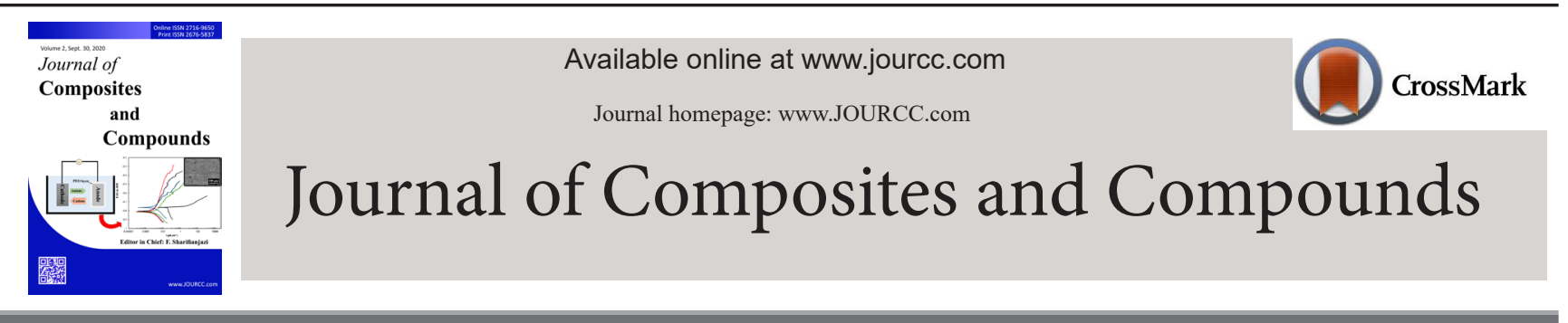

\title{
Concrete filled FRP-PVC tubular columns used in the construction sector: A review
}

\author{
Milad Bazli $^{a *}$, Leila Bazli $^{b}$, Roozbeh Rahmani ${ }^{c}$, Sohail Mansoor ${ }^{d}$, Mohammad Ahmadi ${ }^{\text {, Rasul Pouriamanesh }}{ }^{e}$ \\ ${ }^{a}$ Department of Civil Engineering, Monash University, Clayton, Victoria, Australia \\ ${ }^{b}$ School of Metallurgy and Materials Engineering, Iran University of Science and Technology, Tehran \\ ${ }^{c}$ Department of civil engineering, Faculity of civil engineering, University of Tabriz, Tabriz, Iran \\ ${ }^{d}$ Faculty of Engineering, Christian-Albrechts-University Kiel, Germany \\ ${ }^{e}$ Mahshahr Pipe Mill Co. (MPM), Iran
}

\begin{abstract}
A B S T R A C T
A R T I CLE IN F O RM A TION

In recent years, fiber-reinforced polymer-polyvinyl chloride (FRP-PVC) tubular columns have been used increas- Article history:

ingly in civil engineering applications. Concrete-filled RP-PVC tubes possess high durability, high strengthening Received 25 May 2020

performance, satisfactory bond strength, and compressive behavior. It has been observed that these cost-effec- Received in revised form 07 July 2020

tive tubular columns are promising materials for enhancing strain capacities, strength, and stiffness of structures Accepted 26 September 2020

containing reinforced concrete (RC). These composite tubular columns are composed of FRP and PVC and are used for strengthening concrete. FRP enhances strength capacity while PVC improves the corrosion resistance of Keywords:

concrete piles in harsh environments. This review focuses on the properties of FRP-PVC tubular columns, their Reinforced concrete

application in civil engineering, and the recent advancements in this field.

C2020 JCC Research Group.

Peer review under responsibility of JCC Research Group

FRP-PVC

Tubular columns

Strengthening

Durability
\end{abstract}

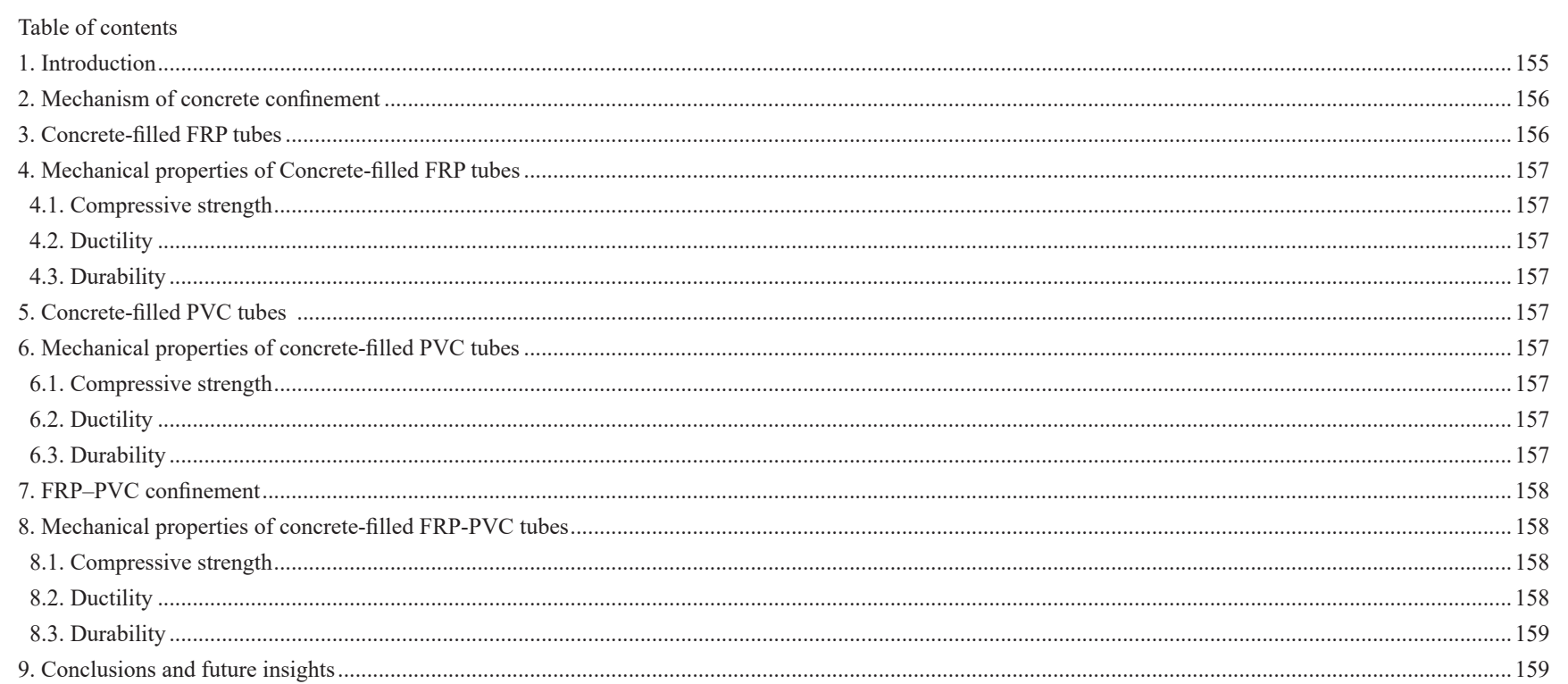

\section{Introduction}

Since its emergence in 1850 , concrete has fulfilled various needs in construction technology. Concrete is extensively used in the construction of bridges, buildings, roads, dams, walls, etc. [1, 2]. It is known

*Corresponding author:Milad Bazli; E-mail: milad.bazli@monash.edu DOR: 20.1001.1.26765837.2019.1.1.4.3

https://doi.org/10.29252/jcc.2.3.7 This is an open access article under the CC BY license (https://creativecommons.org/licenses/by/4.0) that in harsh environments, such as seawater and acidic areas, due to the high amount of chloride and chemical attacks, corrosion of traditional carbon steel reinforcement will be a serious issue if the concrete is reinforced with such reinforcement [3, 4]. Therefore, using corrosion-resistant materials, especially in coastal areas, such as FRP and PVC has been recently proposed to be used together with concrete to address the , 


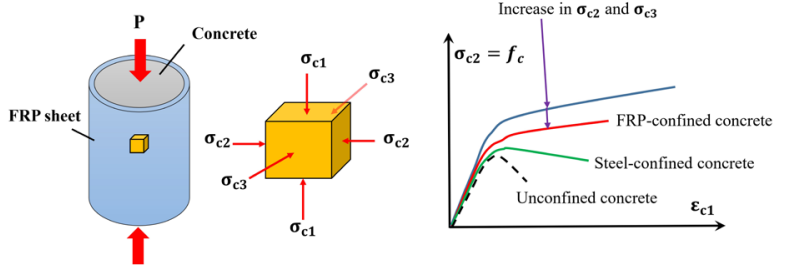

Fig. 1. Stress-strain relationship in concrete confined with FRP.

corrosion problem of traditional steel reinforcement [5-7].

It has been reported that the lateral active or passive confinement by a confining jacket can enhance the mechanical performance and durability of concrete structures $[8,9]$. Different confining jackets in terms of forms and material have been widely investigated to strengthen/rehabilitate new constructions or existing structures [10-12]. These include steel spirals, steel stirrups, pre-stressing strands, hollow tubes/prisms, pre/post-tensioned FRP shells, FRP tubes, FRP composite stirrups, FRP rings, composite ropes, shape memory alloy wraps, and hybrid confining jackets (passive and active) [13-16].

Polymer and polymer composites are gaining increasing attention in various applications $[9,17-22]$. This is due to the possibility to benefit from the combination of properties related to contributing constituents [23-28]. Due to high stiffness, full usage of materials and high strength composite columns have been increasingly used recently [2931]. However, the durability of large sophisticated structures in special environments such as acidic environments and seawater conditions have attracted more attention. Numerous studies in the field of confined concrete columns using different materials showed that using composite material confinement could enhance the ultimate strength by 3 times and the ultimate strain by 15 times. Over the last decades, the replacement of steel bars with FRP rods has been shown to yield better corrosion resistance for structural concrete [5, 32-34].

There are many applications, in which FRP composites can be used in construction and specifically in corrosive environments. Concrete-filled FRP tubes can be used as drilling platforms, bridge, piers, etc. [35-37]. In this regard, many studies have focused on concrete-filled FRP tubes, and mainly on their short-term mechanical properties [38-54].

As a result of stable service performance, low price, and high production volume, PVC has also been used as concrete molds or pipes in the construction industry [55-57]. PVC materials exhibit some advantages such a low creep deformation, low diffusion for humidity, high electrical insulation, large ultimate strain, excellent corrosion resistance and durability, smooth surface, good mechanical stability, great consistency with other materials such as water, acids, and concrete, and easy machining, gluing, and cutting for fabrication versatility [58-60]. There-

Table 1.

Common characteristics of FRP materials

\begin{tabular}{|c|c|c|c|c|c|}
\hline Material & $\begin{array}{c}\text { Fiber } \\
\text { strength } \\
\text { (MPa) }\end{array}$ & $\begin{array}{c}\text { Laminate } \\
\text { density } \\
\text { (g/cc) }\end{array}$ & $\begin{array}{c}\text { Laminated } \\
\text { Strength } \\
\text { (MPa) }\end{array}$ & $\begin{array}{c}\text { Young's } \\
\text { modulus } \\
\text { (GPa) }\end{array}$ & $\begin{array}{c}\text { Strength to } \\
\text { weight } \\
\text { ratio }\end{array}$ \\
\hline Epoxy & - & $1-1.15$ & $12-40$ & 3 & 28 \\
\hline CFRP & 4127 & $1.9-2.1$ & 1600 & $125-181$ & 1013 \\
\hline BFRP & 3792 & $2.6-2.8$ & 1100 & $70-90$ & 1000 \\
\hline GFRP & 3450 & $2.4-2.5$ & 1500 & $30-40$ & 564 \\
\hline $\begin{array}{c}\text { AFRP } \\
\text { (Kevlar) }\end{array}$ & 2757 & 1.44 & 1430 & $\begin{array}{l}70.5- \\
112.4\end{array}$ & 993 \\
\hline
\end{tabular}

fore, FRP-PVC composite members offer both corrosion resistance of PVC and high strength capacity of FRP and they are promising materials for the application in special environments [5, 61-63].

Due to the properties of FRP-PVC composites such as high durability and strength, they are expected to have a reinforcing effect on concrete. Therefore, this paper aims to review the studies on FRP-PVC composites as tubular columns and their potential application in concrete structures.

\section{Mechanism of concrete confinement}

The ultimate compressive strength of a concrete element is remarkably enhanced in the third direction when it is confined in two mutually perpendicular directions. Generally, lateral confinement to concrete is provided by passive confinement or active confinement, e.g. hydraulic pressure. Passive confinement, such as steel stirrups, cause compressive stresses in the element by the imposed elongation on steel stirrups generated by the expansion of concrete. Nevertheless, the element is provided with constant confinement and thereby active confinement after yielding of the steel stirrups. FRP has attracted attention in various structural applications due to its promising properties. Some characteristics of FRP materials are listed in Table 1. For concrete confined with FRP, while the concrete lateral expansion increases, the inward radial pressure is enhanced because of the linear elastic behavior of FRP until failure. Therefore, it is not valid to assume that the presence of a constant confining pressure, and FRP jackets are considered as passive confinement to columns [64].

Moreover, the outer FRP jackets in the form of additional closed hoops effectively improve the shear strength of substandard columns. This enhancement is the result of extra shear reinforcement provided in the jackets. Considering the flexural performance, the concrete columns confined with FRP are provided with the lateral expansion prevention of the core concrete and the longitudinal reinforcement support when axial compressive loading or both lateral and axial compressive loadings are applied on the concrete columns. As a result, compression concrete can bear higher strains before failure, as shown in Fig. 1. Additionally, the concrete compression strength is enhanced by concrete confinement resulting in the improvement of post-cracking behavior i.e. the enhancement of the flexural strength. The application of the external FRP jacket can also enhance the short lap-splice reinforcement behavior. This is caused by the bond stress increase along the splice to delay the splitting onset and alleviate the subsequent deterioration severity and improve the lap-splice performance of defective columns [64]. Richart et al. [65] suggested a simple equation for the determination of hydrostatic fluid pressure-confined concrete (active confinement) as follows:

$f_{c c}^{\prime}=f_{c o}^{\prime}+k_{1} \cdot f_{l u}$

where $f_{c c}^{\prime}$ denotes the confined concrete ultimate strength and $f_{c o}^{\prime}$ represents the compressive strength of unconfined concrete under $f_{l u}$ (maximum lateral pressure).

\section{Concrete-filled FRP tubes}

Owing to excellent anti-corrosion behavior, high durability, as well as high strength-to-weight ratio, FRP has been increasingly utilized in the field of civil engineering [32, 67-72]. FRP-strengthened concrete piles and columns are able to decrease the cost remarkably compared to concrete piles and columns reinforced by steel, particularly in harsh marine environments [36, 73-76]. It has been reported that the USA spends more than $\$ 1$ billion every year for maintaining waterfront piling systems and about $\$ 2$ billion for the replacement and repairing reinforced concrete piers because of the corrosion of steel reinforcement. The re- 
placement of steel with FRP is regarded as a promising approach for overcoming this problem $[8,77,78]$.

FRP grids, FRP helixes, FRP stirrups, FRP rings, and FRP tubes are different forms of FRP lateral confinement for strengthening the concrete columns. Additionally, it has been proven that the externally bonded FRP systems can effectively strengthen the concrete girders or beams. Furthermore, owing to the higher anticorrosion ability and durability of FRP materials, confining with these materials is superior to steel materials for piles in marine environments [79-82].

Concrete filled tubular (CFT) columns, especially the so-called tubed concrete columns are mainly used in construction industries. In these columns, steel bars act as longitudinal reinforcement for the core concrete, and the tube is used for transverse reinforcement. There exists a gap at the end of the tube column to suppress the axial stress transfer into the tube. In typical CFT columns, the tubes are mainly utilized as both longitudinal and transverse reinforcements to bear bending moment and axial forces. The "tubed column" concept was primarily presented by Tomii et al. [83, 84]. They showed the capabilities of steel tube concrete columns by experiments. The definition concept of FRP-tubed and steel-tubed columns concrete is the same. Similar to the results of steel-tubed columns, the excellent properties of FRP-tubed columns have been demonstrated in some studies $[85,86]$.

\section{Mechanical properties of Concrete-filled FRP tubes}

\subsection{Compressive strength}

Ozbakkaloglu et al. [87] studied the axial compressive property of 83 monotonically-loaded high-strength circular concrete-filled FRP tubes (CFFTs) experimentally. The height-to-diameter ratio of the samples was 2 . The parameters affecting the compressive behavior of CFFTs including manufacturing method, concrete strength, fiber type, and specimen size were also investigated. According to the results, the compressive behavior of CFFTs was not noticeably affected by the specimen size. The confinement strength ratio $\left(f_{c c /}^{\prime} f_{c o}^{\prime}\right)$ was obtained in the range of 1.01-2.44. In addition, the strength enhancement ratio $\left(f_{c c /}^{\prime} f_{c o}^{\prime}\right)$ decreased at a specific nominal confinement ratio $\left(f_{l u /}^{\prime} f_{c o}^{\prime}\right)$ owing to an increment in concrete compressive strength $\left(f_{c o}^{\prime}\right)$. Li et al. [88] reported the ratio of the confined concrete strength to unconfined concrete strength ( $f_{c c} / f_{c}$ ) of sea sand and seawater concrete (SWSSC)-filled carbon/glass / basalt-FRP (CFRP/GFRP/BFRP) tubes in the range of 2.08 to 6.86 .

\subsection{Ductility}

Ozbakkaloglu et al. [87] found a correlation between the ultimate axial strain $\left(\varepsilon_{c u}\right)$ of CFFTs and the ultimate tensile strain $\left(\varepsilon_{f u}\right)$ of the fibers. The strain enhancement ratio $\left(\varepsilon_{c u} / \varepsilon_{c o}\right)$ was obtained in the range of 1.34 to 15.31 depending on the manufacturing method, specimen size, concrete strength, and fiber type. They explained that highly ductile behavior was obtained by sufficiently confined high-strength CFFTs. It can be deduced that the level of confinement significantly influences the behavior of the CFFTs, and after the initial peak of strengths, the load-carrying capacity may not be preserved in lightly confined CFFTs.

\subsection{Durability}

The durability is defined as the ability to resist a specific loading or environmental condition for a specific time under a suitable load and environmental condition [89]. Li et al. [88] studied the durability of SWSSC-filled GFRP/CFRP/BFRP tubes during six months by exposing the specimens to artificial seawater containing $3.5 \%$ salt solution at the temperature of $40{ }^{\circ} \mathrm{C}$. Based on the results, the SWSSC compressive strength showed no changes after exposure to seawater, however, in
BFRP and GFRP, an evident hoop strength degradation was exhibited. Mechanical properties of SWSSC-filled FRP tubes, such as ultimate axial strain and strength decreased as a result of environmental aging and the hoop strength deterioration of FRP was considered as the major mechanism. The ratio of $f_{c c} / f_{c}$ was obtained for exposed and unexposed samples and exposed-to-unexposed ratios of $f_{c c} / f_{c}$ ranged from 0.47 to 0.77 .

\section{Concrete-filled PVC tubes}

The aims of using PVC tubes in concrete columns are the improvement of the deformation capacity of concrete and accommodation of the electrical wiring, wastewater, and rain. Kurt [90] experimentally and theoretically studied commercial PVC tubes filled with a concrete core. The results exhibited that the PVC tubes enhanced the concrete core strength to approximately 3.2 times the pipe burst pressure. The encasement holds the circular shape of the flexible tube and also supports most of the external loads [8]. It can be mentioned that tube ring compression stress should be below the yield strength. PVC inner-steel outer tubes as well as double-skin tubes filled with concrete were analyzed under axial load. As the results demonstrated, under moderate load conditions, the PVC tube can be considered as a good alternative material for steel one [91]. Xue et al. [92] investigated seismic performance as well as the deformation capacity of PVC tube-filled high-strength concrete short columns (PVC-RHC) under quasi-static loadings and test variables including shear span ratio, axial compression ratio, and PVC tube diameter. The ductility factor between 3.35 and 4.61 was obtained for PVCRHC columns, in comparison with 1.94 for RHC. With an increase in the diameter/height ratio of PVC tube, ultimate capacity, and ductility increase.

\section{Mechanical properties of concrete-filled PVC tubes}

\subsection{Compressive strength}

The concrete confinement with PVC tubes improves the damage characteristics and the bearing capacity of the concrete core. According to Xue et al. [92], the average of confinement strength ratios for concrete-filled PVC tubes with an $\mathrm{h} / \mathrm{D}$ ratio of 2 was obtained in the range of 1.0-3.04 [8,93]. Different parameters contribute to the variation of the two values such as testing conditions, concrete infill strength, PVC tube geometry, and the size of specimens. Furthermore, the analyses showed that at the $\mathrm{D} / \mathrm{t}$ ratio in the range of $20-35$, optimum $f_{c c} / f_{u c}$ values were obtained.

\subsection{Ductility}

The PVC tube is described through a combination of two contradictions; a ductile plastic or a type of rigid elastic material. Some studies showed that the variation of the confined to the unconfined strain ratio was between 1.415 and 5.54 for concrete-filled PVC tubes with the $h / D$ ratio of 2 (Table 2). In addition, the range of $2000-3945 \mathrm{~kJ} / \mathrm{m} 3$ was reported for the energy absorption capacity [94, 95]. Generally, PVC tubular specimens with low wall thicknesses showed the improvement of the deformation capacity and energy dissipating of concrete columns and as the thickness of PVC tube increases, ductility improvement is obtained $[92,94]$.

\subsection{Durability}

Commercially available thermoplastic pipes, like PVC pipes, have shown the ability to enhance the durability of reinforced concrete (RC) structures $[90,94,96,97]$. No deterioration was observed in PVC pipes 


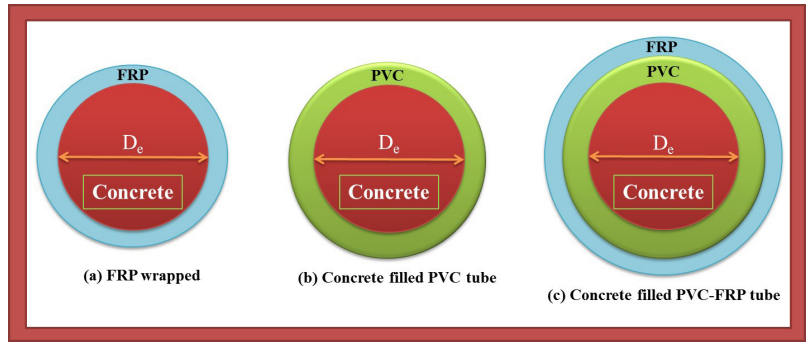

Fig. 2. Concrete pile confined with a) FRP wrap, b) PVC tube, and c) PVC-FRP composite tube.

buried in the soil after 60 years and they showed extended life of 50 years [98]. The thermal conductivity of PVC is around $0.45 \sim 0.6 \%$ of steel tubes providing a stable condition for core concrete curing, which leads to high durability together with high performance [97]. A study by Gupta et al. [99] indicated that there is no strength degradation ductility for RC-filled PVC specimens exposed to harsh environments. Based on the test results, no significant changes in the chemical composition and microstructure of the PVC jackets were observed after 6 months for RCfilled-PVC tubes immersed in saturated seawater. The improvement of PVC durability provides a system with potential applications for many different structures that are exposed to saline and marine environmental conditions.

A study on natural aging and accelerated aging of PVC by Jakubowicz et al. [100] revealed no evident changes in elongation at fracture and mechanical properties of $\mathrm{PVC}$ material after eight weeks of aging in the air at $80^{\circ} \mathrm{C}$. Due to the PVC great anti-corrosion behavior, FRP jackets can compensate the relatively poor confining effect of PVC tubes and provide significant durability and mechanical strength for the confined concrete-filled PVC tubes.

\section{FRP-PVC confinement}

There are many research works on applying plastic pipes such as PVC to overcome the relative low ultimate strain and ductility of FPR [102]. It is a widely used polymer in various products including medical devices, pipes, flooring, and profiles for windows and doors. As a result of excellent physical, mechanical, and chemical properties, PVC is considered a "natural" fire-resistant material [103]. A hybrid column system for new constructions is proposed by Toutanji et al. [104], in which PVC tubes are filled with concrete and the external confinement is provided by continuous impregnated FRP hoops that may have various spacing. It has been proposed that FRP-PVC tubes are effective confinements for improving both failure strains and the strength of concrete. Fakharifar et al. [8] studied the mechanical behavior of concrete confined with PVC, FRP, and FRP-PVC. The FRP-PVC confined concrete indicated higher ultimate strain and strength compared to the FRP and PVC ones [77]. Table 2.

Confinement ratio $\left(\mathrm{f}_{\mathrm{cc}} / \mathrm{f}_{\mathrm{uc}}\right)$ and ductility of concrete-filled PVC tubes

\begin{tabular}{ccccc}
\hline Ref. & $\begin{array}{c}\mathbf{h} / \mathbf{D} \\
(\mathbf{m m})\end{array}$ & $\mathbf{f}_{\mathrm{cc}} / \mathbf{f}_{\mathrm{uc}}$ & $\boldsymbol{\varepsilon}_{\mathrm{cu}} / \boldsymbol{\varepsilon}_{\mathrm{uc}}$ & $\mathbf{t}(\mathbf{m m})$ \\
\hline Kurt [90] & 2 & 1.718 & - & 6.4 \\
Wang and Yang [94] & 2 & $1.011-2.345$ & $1.415-5.540$ & $3.7-8.5$ \\
Saadoon [101] & 2 & $1.118-1.688$ & $1.686-2.473$ & $3.2-5.3$ \\
Fakharifar and Chen [8] & 1.8 & $0.966-1.050$ & $1.81-4.07$ & 7.1 \\
Oyawa et al. [93] & 2 & $1.180-3.040$ & - & $2.5-3.0$ \\
\hline
\end{tabular}

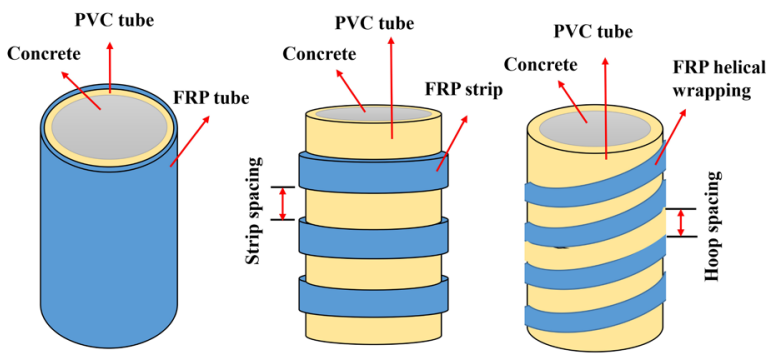

Fig. 3. Schematic of the placement of FRP-PVC tube

The FRP-PVC-confined concrete system is shown in Fig. 2 and different FRP-PVC-confined concrete systems are shown in Fig. 3.

\section{Mechanical properties of concrete-filled FRP-PVC tubes}

\subsection{Compressive strength}

There are numerous studies conducted regarding the compressive properties of FRP-PVC tubular columns. Several parameters, including the concrete characteristics and FRP-PVC properties, were investigated [8, 56, 58-62, 104-114]. In a study by Toutanji and Saafi [96], it was reported that the strength of PVC-FRP confined concrete (with h/D of 3) was high. The FRP-PVC tubes provided lateral confinement and created triaxial stress in the concrete, which constrained concrete during dilation and consequently, enhanced its capacity of load bearing. The compressive strength enhancement ratio $\left(\left(f_{c u}-f_{c o}\right) / f_{c o}\right)$ was reported to range from 0 to 1.9 depending on the fiber type and hoop spacing. In a study by Mammen and Antony [109], concrete-filled PVC tubes (h/ $\mathrm{D}=2.1$ ) with various thicknesses were wrapped with GFRP and CFRP. They confined concrete with two different patterns of circular and helical wrapping with two different hoop spacing in a way to decrease the amount of required FRP. Higher-strength was achieved for carbon fiber circular wrapping and larger PVC thickness (ultimate strength of 33.5 $\mathrm{MPa})$.

Fakharifar et al. [115] provided confinement using a PVC tube (with $\mathrm{h} / \mathrm{D}$ of 2) and FRP wrappings or FRP containing a layer of foam to reduce impact energy resulting from the potential rupture of FRP and fracture of PVC. The results showed that the contribution of the PVC tube to the axial strength of concrete was insignificant, however, the strength of the columns enhanced more significantly when FRP wraps in which fibers oriented in hoop direction were used. The strength enhancement ratios $\left(f_{c u} / f_{c o}\right)$ were obtained between 1.08 and 2.29 for the samples.

The improvement of the ductility as well as the strength of FRPPVC tube-confined recycled aggregate concrete was studied by Gao et al. [58]. As the results demonstrated, the compressive strength enhancement of the samples confined with the FRP-PVC hybrid system ranged from $4.5 \%$ to $39.6 \%$. Moreover, a thicker FRP tube or strip led to a higher improvement in deformation and strength.

\subsection{Ductility}

Toutanji and Saafi [96] also reported the ductility enhancement of PVC-FRP confined concrete. The ductility increase $\left(\left(\varepsilon_{c u}-\varepsilon_{c o}\right) / \varepsilon_{c o}\right)$ for the samples with different fiber types and hoop spacing was between $0-9$. In the research by Fakharifar et al. [115], it was stated that the addition of FRP wraps with hoop-directed fibers around PVC tubes increased the ductility of the columns significantly. The strain enhancement ratios 
Table 3.

Confinement ratio $\left(\mathrm{f}_{\mathrm{cc}} / \mathrm{f}_{\mathrm{uc}}\right)$ and ductility of concrete-filled FRP-PVC tubes

\begin{tabular}{cccc}
\hline Ref. & $\mathbf{h} / \mathbf{D}(\mathbf{m m})$ & $\mathbf{f}_{\mathrm{cc}} / \mathbf{f}_{\mathrm{uc}}$ & $\boldsymbol{\varepsilon}_{\mathrm{cu}} / \boldsymbol{\varepsilon}_{\mathrm{uc}}$ \\
\hline Fakharifar [8] & 2 & $1.08-2.29$ & $2.14-12.21$ \\
Gao [58] & 2 & $0.2-1.13$ & $3.95-14.2$ \\
Toutanji [111] & 3 & $1.31-2.81$ & $1.55-9$ \\
\hline
\end{tabular}

$\left(\varepsilon_{c u} / \varepsilon_{c o}\right)$ of the specimens were obtained from 2.14 to 12.21 . After the rupture of the FRP wraps, the interior PVC tube fractured immediately leading to an instant drop in load-carrying capacity. The authors proposed that by placing a layer of foam between the FRP wraps and PVC tube as an energy absorber, this brittle failure mode could be avoided. The use of this layer causes a gradual reduction of the strength in steps. Therefore, the foam layer proved to have a significant effect on the reduction of brittleness providing a relatively ductile response upon the rupture of FRP.

Yu et al. [116] reported that by an increase in the ratio of shear span or axial compression, elastic-plastic displacement angles and the displacement ductility coefficient of RC columns confined with CFRPPVC under low cyclic loading were reduced gradually. Furthermore, the angles of elastic-plastic displacement together with the displacement ductility coefficient of the samples were gradually enhanced by the decrease in the hoop spacing of FRP strips. Fang et al. [107] conducted an experimental investigation on the concrete stub columns confined with CFRP-PVC under the axial compression condition. They investigated the influence of CFRP strip spacing on the mechanical properties of the confined stub columns. The obtained values of $\varepsilon_{c u} / \varepsilon_{c o}$ were reported to be between 6.3 and 9.1, indicating the provision of significant confinement on core concrete by the CFRP-PVC tubes. Apparently, by an increase in the spacing of CFRP strips, this ratio is gradually reduced. The mechanical properties of concrete-filled FRP-PVC tubes are summarized in Table 3 .

\subsection{Durability}

Despite the outstanding characteristics of FRP/PVC composites, their durability under harsh environmental conditions is still a serious concern [117]. There are numerous studies available on the short-term and long-term durability of different FRP/PVC composites as the main element and reinforcing members under various environmental conditions [95, 118-122]. In this regard, previous studies conducted on the durability of the mechanical properties of FRP composites under alkaline environment (i.e. when using FRP/PVC with concrete), have shown that such condition is detrimental to some types of FRP/PVC composites [119]. Therefore, the durability of composite-reinforced concrete structures in harsh environmental conditions (e.g. alkaline, acidic, and marine environments as well as elevated temperatures) has always been a major concern [33, 96, 118, 123-128]. The U.S. allocates more than $\$ 1$ billion annually for repairing and replacing waterfront piling systems [8].

Toutanji and Saafi [96] fabricated composite columns composed of a hybrid FRP-PVC tube with a concrete core and studied the performance of these concrete columns in various environmental conditions including ambient temperature, wet and dry, as well as freezing and thawing conditions. According to the durability results, confining concrete with CFRP-PVC composite resulted in good performance under the severe exposures, however, a decrease in both ductility and strength was observed in the AFRP-PVC (aramid FRP) and concrete filled-GFRP-PVC samples. Upon 400 freezing/thawing cycles, AFRP-PVC specimens exhibited around $10 \%$ strength reduction while $10 \%$ reduction was observed for the AFRP-PVC specimens.

In another study by Toutanji et al. [129], the durability performance of concrete filled-FRP-PVC under freezing/thawing and wet/dry con- ditions was studied. According to the results, there was an insignificant influence on ductility as well as the strength of all samples. No reduction of strength was observed after wet/dry cycles (200 and 400 cycles) in PVC-CFRP confined concrete. However, due to the reduction of axial strain after $400 \mathrm{wet} /$ dry cycles, the ductility of the samples decreased. GFRP-PVC and AFRP-PVC confined concrete underwent the reduction of axial strain and the strength only after wet/dry cycles of 400. Additionally, a noticeable decrement in the axial strain of the AFRP-PVC and GFRP-PVC confined samples occurred after 400 cycles of freezing/ thawing. Generally, the CFRP-PVC concrete specimens showed lower strain reduction compared to other samples.

\section{Conclusions and future insights}

In recent decades, researchers have focused on using new materials to confine concrete members laterally for construction applications. The improvement of the existing knowledge along with the exploration of other beneficial and inexpensive alternatives to confining concrete members will provide a viable solution for sustainable construction. This article deals with an overview of the application of FRP-PVC tubular columns strengthening method for concrete structure reinforcement. According to previous investigations, concrete columns confined with FRP-PVC render excellent ductility, high bearing capacity, timesaving convenient construction, and outstanding applicability in normal conditions together with aggressive environments, good durability characteristics, as well as being lightweight. This system is suitable for harsh environments and offshore marine structures due to the corrosion resistance of PVC. However, further laboratory studies, field investigations, as well as detailed information from experimental and analytical investigations are needed to develop proper design guidelines. By applying the established measures, introducing practical composite-based systems in civil construction works will be facilitated.

\section{Acknowledgments}

The authors received no financial support for the research, authorship and/or publication of this article.

\section{Conflict of Interest}

All authors declare no conflicts of interest in this paper.

\section{REFERENCES}

[1] S. Hemavathi, A. Sumil Kumaran, R. Sindhu, An experimental investigation on properties of concrete by using silica fume and glass fibre as admixture, Materials Today: Proceedings 21 (2020) 456-459.

[2] M. Gunavel, S. Aishwarya, K. Indhumathi, N. Jalapriya, M.K. Priya, Proportioning of Lightweight Concrete by the Inclusion of Expanded Polystyrene (EPS), International Journal of Engineering Research \& Technology 9(2) (2020).

[3] L. Wang, Z. Yang, Y. Cui, B. Wei, S. Xu, J. Sheng, M. Wang, Y. Zhu, W. Fei, Graphene-copper composite with micro-layered grains and ultrahigh strength, Scientific Reports 7(1) (2017) 41896.

[4] M. Bazli, X.-L. Zhao, R.S. Raman, Y. Bai, S. Al-Saadi, Bond performance between FRP tubes and seawater sea sand concrete after exposure to seawater condition, Construction and Building Materials 265 (2020) 120342.

[5] S.-F. Jiang, S.-L. Ma, Z.-Q. Wu, Experimental study and theoretical analysis on slender concrete-filled CFRP-PVC tubular columns, Construction and Building Materials 53 (2014) 475-487.

[6] J. Teng, T. Yu, J. Dai, G. Chen, FRP composites in new construction: current status and opportunities, Proceedings of 7th National Conference on FRP Composites in Infrastructure (Supplementary Issue of Industrial Construction), keynote presentation, Hangzhou, China, 2011.

[7] M. Bazli, X.-L. Zhao, A. Jafari, H. Ashrafi, Y. Bai, R.S. Raman, H. Khezrzadeh, Mechanical properties of pultruded GFRP profiles under seawater sea sand concrete environment coupled with UV radiation and moisture, Construction and Building Materials (2020) 120369 
[8] M. Fakharifar, G. Chen, Compressive behavior of FRP-confined concrete-filled PVC tubular columns, Composite Structures 141 (2016) 91-109.

[9] S. Saadi, B. Nazari, Recent developments and applications of nanocomposites in solar cells: a review, Journal of Composites and Compounds 1(1) (2019) 48-58. [10] Z. Yan, C.P. Pantelides, L.D. Reaveley, Posttensioned FRP composite shells for concrete confinement, Journal of Composites for Construction 11(1) (2007) 81-90.

[11] K.N. Nesheli, K. Meguro, Seismic retrofitting of earthquake-damaged concrete columns by lateral pre-tensioning of FRP belts, Proc., 8th US National Conf. on Earthquake Engineering, Earthquake Engineering Research Institute (EERI) El Cerrito, CA, 2006

[12] B. Wang, E.V. Bachtiar, L. Yan, B. Kasal, V. Fiore, Flax, Basalt, E-Glass FRP and Their Hybrid FRP Strengthened Wood Beams: An Experimental Study, Polymers 11(8) (2019) 1255.

[13] T.C. Rousakis, I.S. Tourtouras, RC columns of square section-passive and active confinement with composite ropes, Composites Part B: Engineering 58 (2014) 573-581.

[14] M. Shin, B. Andrawes, Experimental investigation of actively confined concrete using shape memory alloys, Engineering Structures 32(3) (2010) 656-664.

[15] E. Choi, B.-S. Cho, S. Lee, Seismic retrofit of circular RC columns through using tensioned GFRP wires winding, Composites Part B: Engineering 83 (2015) 216-225.

[16] A.U. Al-saadi, T. Aravinthan, W. Lokuge, Structural applications of fibre reinforced polymer (FRP) composite tubes: A review of columns members, Composite Structures 204 (2018) 513-524.

[17] M. Arefian, M. Hojjati, I. Tajzad, A. Mokhtarzade, M. Mazhar, A. Jamavari, A review of Polyvinyl alcohol/Carboxiy methyl cellulose (PVA/CMC) composites for various applications, Journal of Composites and Compounds 2(3) (2020) 6976.

[18] A. Abuchenari, K. Hardani, S. Abazari, F. Naghdi, M.A. Keleshteri, A. Jamavari, A.M. Chahardehi, Clay-reinforced nanocomposites for the slow release of chemical fertilizers and water retention, Journal of Composites and Compounds 2(3) (2020) 85-91.

[19] S.O. Omid, Z. Goudarzi, L.M. Kangarshahi, A. Mokhtarzade, F. Bahrami, Self-expanding stents based on shape memory alloys and shape memory polymers, Journal of Composites and Compounds 2(3) (2020) 92-98

[20] H.W. Jang, A. Zareidoost, M. Moradi, A. Abuchenari, A. Bakhtiari, R. Pouriamanesh, B. Malekpouri, A.J. Rad, D. Rahban, Photosensitive nanocomposites: environmental and biological applications, Journal of Composites and Compounds 2(1) (2020) 50-60.

[21] A. Kazemzadeh, H. Kazemzadeh, Determination of $\mathrm{Hg}^{2+}$ by Diphenylcarbazone Compound in Polymer Film, Journal of Composites and Compounds 1(1) (2019) 30-35

[22] L. Bazli, M.H. Bagherian, M. Karrabi, F. Abbassi-Sourki, H. Azizi, Effect of starch ratio and compatibilization on the viscoelastic behavior of POE/starch blends, Journal of Applied Polymer Science 137(29) (2020) 48877.

[23] P. Abasian, M. Radmansouri, M.H. Jouybari, M.V. Ghasemi, A. Mohammadi, M. Irani, F.S. Jazi, Incorporation of magnetic NaX zeolite/DOX into the PLA/chitosan nanofibers for sustained release of doxorubicin against carcinoma cells death in vitro, International journal of biological macromolecules 121 (2019) 398-406. [24] M. Radmansouri, E. Bahmani, E. Sarikhani, K. Rahmani, F. Sharifianjazi, M. Irani, Doxorubicin hydrochloride-Loaded electrospun chitosan/cobalt ferrite/titanium oxide nanofibers for hyperthermic tumor cell treatment and controlled drug release, International journal of biological macromolecules 116 (2018) 378-384 [25] B.F. Dizaji, M.H. Azerbaijan, N. Sheisi, P. Goleij, T. Mirmajidi, F. Chogan, M. Irani, F. Sharafian, Synthesis of PLGA/chitosan/zeolites and PLGA/chitosan/metal organic frameworks nanofibers for targeted delivery of Paclitaxel toward prostate cancer cells death, International Journal of Biological Macromolecules (2020).

[26] L. Bazli, A. Khavandi, M.A. Boutorabi, M. Karrabi, Morphology and viscoelastic behavior of silicone rubber/EPDM/Cloisite 15A nanocomposites based on Maxwell model, Iranian Polymer Journal 25(11) (2016) 907-918.

[27] L. Bazli, A. Khavandi, M.A. Boutorabi, M. Karrabi, Correlation between viscoelastic behavior and morphology of nanocomposites based on SR/EPDM blends compatibilized by maleic anhydride, Polymer 113 (2017) 156-166.

[28] A. Kazemzadeh, M.A. Meshkat, H. Kazemzadeh, M. Moradi, R. Bahrami, R. Pouriamanesh, Preparation of graphene nanolayers through surfactant-assisted pure shear milling method, Journal of Composites and Compounds 1(1) (2019) 25-30.

[29] M. Bazli, X.-L. Zhao, A. Jafari, H. Ashrafi, R.S. Raman, Y. Bai, H. Khezrzadeh, Durability of glass-fibre-reinforced polymer composites under seawater and sea-sand concrete coupled with harsh outdoor environments, Advances in Structural Engineering (2020) 1369433220947897.
[30] Z. Huang, D. Li, B. Uy, H.-T. Thai, C. Hou, Local and post-local buckling of fabricated high-strength steel and composite columns, Journal of Constructional Steel Research 154 (2019) 235-249.

[31] D. Li, Z. Huang, B. Uy, H.-T. Thai, C. Hou, Slenderness limits for fabricated S960 ultra-high-strength steel and composite columns, Journal of Constructional Steel Research 159 (2019) 109-121.

[32] H. Ashrafi, M. Bazli, A.V. Oskouei, Enhancement of bond characteristics of ribbed-surface GFRP bars with concrete by using carbon fiber mat anchorage, Construction and Building Materials 134 (2017) 507-519.

[33] M. Bazli, H. Ashrafi, A.V. Oskouei, Experiments and probabilistic models of bond strength between GFRP bar and different types of concrete under aggressive environments, Construction and Building Materials 148 (2017) 429-443.

[34] M. Bazli, Y.L. Li, X.L. Zhao, R.S. Raman, Y. Bai, S. Al-Saadi, A. Haque, Durability of seawater and sea sand concrete filled filament wound FRP tubes under seawater environments, Composites Part B: Engineering (2020) 108409.

[35] J. Wang, P. Feng, T. Hao, Q. Yue, Axial compressive behavior of seawater coral aggregate concrete-filled FRP tubes, Construction and Building Materials 147 (2017) 272-285

[36] M. Bazli, X.-L. Zhao, Y. Bai, R.S. Raman, S. Al-Saadi, A. Haque, Durability of pultruded GFRP tubes subjected to seawater sea sand concrete and seawater environments, Construction and Building Materials 245 (2020) 118399

[37] M. Bazli, X.-L. Zhao, Y. Bai, R.S. Raman, S. Al-Saadi, Bond-slip behaviour between FRP tubes and seawater sea sand concrete, Engineering Structures 197 (2019) 109421

[38] Y.L. Li, X.L. Zhao, R.K. Raman Singh, S. Al-Saadi, Tests on seawater and sea sand concrete-filled CFRP, BFRP and stainless steel tubular stub columns, ThinWalled Structures 108 (2016) 163-184

[39] Y.L. Li, X.L. Zhao, R.K. Raman Singh, S. Al-Saadi, Experimental study on seawater and sea sand concrete filled GFRP and stainless steel tubular stub columns, Thin-Walled Structures 106 (2016) 390-406.

[40] G.M. Chen, Z.B. He, T. Jiang, J.F. Chen, J.G. Teng, Axial compression tests on FRP-confined seawater/sea-sand concrete, 6th Asia-Pacific Conference on FRP in Structures, 2017.

[41] Y.L. Li, J.G. Teng, X.L. Zhao, R.K. Singh Raman, Theoretical model for seawater and sea sand concrete-filled circular FRP tubular stub columns under axial compression, Engineering Structures 160 (2018) 71-84

[42] C. Lu, A. Fam, The effect of tube damage on flexural strength of $\pm 55^{\circ}$ angle-ply concrete-filled FRP tubes, Construction and Building Materials 240 (2020) 117948.

[43] H. Tian, Z. Zhou, Y. Wei, J. Lu, Behavior and Modeling of Ultra-High Performance Concrete-Filled FRP Tubes Under Cyclic Axial Compression, Journal of Composites for Construction 24(5) (2020) 04020045.

[44] A.M. Ali, R. Masmoudi, Composite Action Assessment of Concrete-Filled FRP Tubes Subjected to Flexural Cyclic Load, Engineering Structures 203 (2020) 109889.

[45] H. Lee, H. Jang, W. Chung, Effect of Recycled Concrete on the Flexural Behavior of Concrete-Filled FRP Tubes, International Journal of Concrete Structures and Materials 13(1) (2019) 12.

[46] A.F. Pour, A. Gholampour, J. Zheng, T. Ozbakkaloglu, Behavior of FRP-confined high-strength concrete under eccentric compression: tests on concrete-filled FRP tube columns, Composite Structures 220 (2019) 261-272.

[47] Z. Chen, J. Wang, J. Chen, H. GangaRao, R. Liang, W. Liu, Responses of concrete-filled FRP tubular and concrete-filled FRP-steel double skin tubular columns under horizontal impact, Thin-Walled Structures 155 (2020) 106941.

[48] H. Tian, Z. Zhou, Y. Wei, Y. Wang, J. Lu, Experimental investigation on axial compressive behavior of ultra-high performance concrete (UHPC) filled glass FRP tubes, Construction and Building Materials 225 (2019) 678-691.

[49] Y. Zhang, Y. Wei, J. Bai, Y. Zhang, Stress-strain model of an FRP-confined concrete filled steel tube under axial compression, Thin-Walled Structures 142 (2019) 149-159.

[50] Y.-L. Li, X.-L. Zhao, R.S. Raman, Behaviour of seawater and sea sand concrete filled FRP square hollow sections, Thin-Walled Structures 148 (2020) 106596.

[51] A.M. Ali, R. Masmoudi, Experimental and analytical investigation of new concrete filled FRP tube beam-column connections, Engineering Structures 191 (2019) 311-322.

[52] Y. Zhang, Y. Wei, J. Bai, G. Wu, Z. Dong, A novel seawater and sea sand concrete filled FRP-carbon steel composite tube column: Concept and behaviour, Composite Structures (2020) 112421.

[53] P. Xie, G. Lin, J. Teng, T. Jiang, Modelling of concrete-filled filament-wound FRP confining tubes considering nonlinear biaxial tube behavior, Engineering Structures 218 (2020) 110762. 
[54] M.J. Abyaneh, H. El Naggar, P. Sadeghian, Numerical Modeling of the Lateral Behavior of Concrete-Filled FRP Tube Piles in Sand, International Journal of Geomechanics 20(8) (2020) 04020108.

[55] K. Gonnade, R. Khapre, Experimental and Computational Study on Concrete Filled PVC Plastic Tubes Placed In Columns, Helix 10(01) (2020) 165-169.

[56] S.M. Askari, A. Khaloo, M.H. Borhani, M.S.T. Masoule, Performance of polypropylene fiber reinforced concrete-filled UPVC tube columns under axial compression, Construction and Building Materials 231 (2020) 117049.

[57] Ö.B. Ceran, B. Şimşek, T. Uygunoğlu, O.N. Şara, PVC concrete composites: comparative study with other polymer concrete in terms of mechanical, thermal and electrical properties, Journal of Material Cycles and Waste Management 21(4) (2019) 818-828.

[58] C. Gao, L. Huang, L. Yan, R. Jin, B. Kasal, Strength and ductility improvement of recycled aggregate concrete by polyester FRP-PVC tube confinement, Composites Part B: Engineering 162 (2019) 178-197.

[59] F. Yu, D. Li, D. Niu, D. Zhu, Z. Kong, N. Zhang, Y. Fang, A model for ultimate bearing capacity of PVC-CFRP confined concrete column with reinforced concrete beam joint under axial compression, Construction and Building Materials 214 (2019) 668-676.

[60] F. Yu, Z. Song, I. Mansouri, J. Liu, Y. Fang, Experimental study and finite element analysis of PVC-CFRP confined concrete column-Ring beam joint subjected to eccentric compression, Construction and Building Materials 254 (2020) 119081. [61] H. Zhang, M.N. Hadi, Geogrid-confined pervious geopolymer concrete piles with FRP-PVC-confined concrete core: Analytical models, Structures, Elsevier, 2020, pp. 731-738

[62] F. Yu, N. Zhang, Y. Fang, J. Liu, G. Xiang, Stress-strain model of weak PVCFRP confined concrete column and strong RC ring beam joint under eccentric compression, Steel and Composite Structures 35(1) (2020) 13-27.

[63] Y.-C. Guo, S.-H. Xiao, S.-W. Shi, J.-J. Zeng, W.-Q. Wang, H.-C. Zhao, Axial Compressive Behavior of Concrete-Filled FRP-Steel Wire Reinforced Thermoplastics Pipe Hybrid Columns, Composite Structures (2020) 112237.

[64] Z. Wu, Y. Wu, M.F.M. Fahmy, 6 - FRP strengthening of concrete columns, in: Z. Wu, Y. Wu, M.F.M. Fahmy (Eds.), Structures Strengthened with Bonded Composites, Woodhead Publishing2020, pp. 387-480.

[65] F.E. Richart, A. Brandtzæg, R.L. Brown, A study of the failure of concrete under combined compressive stresses, University of Illinois at Urbana Champaign, College of Engineering ..., 1928.

[66] Y.M. Amran, R. Alyousef, R.S. Rashid, H. Alabduljabbar, C.-C. Hung, Properties and applications of FRP in strengthening RC structures: A review, Structures, Elsevier, 2018, pp. 208-238.

[67] M.H. Khaneghahi, E.P. Najafabadi, M. Bazli, A.V. Oskouei, X.-L. Zhao, The effect of elevated temperatures on the compressive section capacity of pultruded GFRP profiles, Construction and Building Materials 249 (2020) 118725.

[68] H. Ashrafi, M. Bazli, A. Jafari, T. Ozbakkaloglu, Tensile properties of GFRP laminates after exposure to elevated temperatures: Effect of fiber configuration, sample thickness, and time of exposure, Composite Structures 238 (2020) 111971. [69] E.P. Najafabadi, M. Bazli, H. Ashrafi, A.V. Oskouei, Effect of applied stress and bar characteristics on the short-term creep behavior of FRP bars, Construction and Building Materials 171 (2018) 960-968.

[70] A.V. Oskouei, A. Jafari, M. Bazli, R. Ghahri, Effect of different retrofitting techniques on in-plane behavior of masonry wallettes, Construction and Building Materials 169 (2018) 578-590.

[71] A.V. Oskouei, M.P. Kivi, H. Araghi, M. Bazli, Experimental study of the punching behavior of GFRP reinforced lightweight concrete footing, Materials and Structures 50(6) (2017) 256

[72] A. Jafari, A.V. Oskouei, M. Bazli, R. Ghahri, Effect of the FRP sheet's arrays and NSM FRP bars on in-plane behavior of URM walls, Journal of Building Engineering 20 (2018) 679-695.

[73] M.N.S. Hadi, Q.S. Khan, M.N. Sheikh, Axial and flexural behavior of unreinforced and FRP bar reinforced circular concrete filled FRP tube columns, Construction and Building Materials 122 (2016) 43-53.

[74] A.D. Mai, M.N. Sheikh, M.N.S. Hadi, Investigation on the behaviour of partial wrapping in comparison with full wrapping of square RC columns under different loading conditions, Construction and Building Materials 168 (2018) 153-168. [75] A. Kashi, A.A. Ramezanianpour, F. Moodi, Durability evaluation of retrofitted corroded reinforced concrete columns with FRP sheets in marine environmental conditions, Construction and Building Materials 151 (2017) 520-533.

[76] A.N. Ababneh, R.Z. Al-Rousan, I.M. Ghaith, Experimental study on anchoring of FRP-strengthened concrete beams, Structures, Elsevier, 2020, pp. 26-33.

[77] H. Zhang, M.N.S. Hadi, Geogrid-confined pervious geopolymer concrete piles with FRP-PVC-confined concrete core: Analytical models, Structures 23 (2020) $731-738$
[78] F. Micelli, R. Mazzotta, M. Leone, M.A. Aiello, Review Study on the Durability of FRP-Confined Concrete, Journal of Composites for Construction 19(3) (2015) 04014056.

[79] H. Zhang, M.N. Hadi, Geogrid-confined pervious geopolymer concrete piles with FRP-PVC-confined concrete core: Concept and behaviour, Construction and Building Materials 211 (2019) 12-25.

[80] X. Yang, W.-Y. Gao, J.-G. Dai, Z.-D. Lu, Shear strengthening of RC beams with FRP grid-reinforced ECC matrix, Composite Structures (2020) 112120.

[81] Y. Wang, G. Chen, B. Wan, G. Cai, Y. Zhang, Behavior of circular ice-filled self-luminous FRP tubular stub columns under axial compression, Construction and Building Materials 232 (2020) 117287.

[82] M. Lindner, K. Vanselow, S. Gelbrich, L. Kroll, Fibre-reinforced polymer stirrup for reinforcing concrete structures.

[83] M. Tomii, Lateral Load Capacity of Reinforced Concrete Short Columns Confined by Stell Tube-Experimental Results of Preliminary Research, Proceedings of the International Specialty Confernce on Concrete-Filled Steel Tubular Structures (1985) 19-26.

[84] M. Tomii, K. Sakino, Y. Xiao, K. Watanabe, Earthquake resisting hysteretic behavior of reinforced concrete short columns confined by steel tube, Proceedings of the International Speciality Conference on Concrete Filled Steel Tubular Structures, Harbin, China, 1985, pp. 119-25.

[85] Y. Xiao, Applications of FRP composites in concrete columns, Advances in Structural Engineering 7(4) (2004) 335-343.

[86] A. Raza, A. ur Rehman, B. Masood, I. Hussain, Finite element modelling and theoretical predictions of FRP-reinforced concrete columns confined with various FRP-tubes, Structures, Elsevier, 2020, pp. 626-638

[87] T. Ozbakkaloglu, T. Vincent, Axial compressive behavior of circular highstrength concrete-filled FRP tubes, Journal of composites for construction 18(2) (2014) 04013037

[88] Y.L. Li, X.L. Zhao, R.K. Singh Raman, Mechanical properties of seawater and sea sand concrete-filled FRP tubes in artificial seawater, Construction and Building Materials 191 (2018) 977-993.

[89] A. Parghi, M.S. Alam, A review on the application of sprayed-FRP composites for strengthening of concrete and masonry structures in the construction sector, Composite Structures 187 (2018) 518-534.

[90] C.E. Kurt, Concrete filled structural plastic columns, Journal of the Structural Division 104(ASCE 13478 Proceeding) (1978).

[91] R.K. Watkins, Buried pipe encased in concrete, Pipeline Engineering and Construction: What's on the Horizon?2004, pp. 1-10

[92] J. Xue, H. Li, L. Zhai, X. Ke, W. Zheng, B. Men, Analysis on influence parameters and mechanical behaviors of embedded PVC pipe confined with reinforced high-strength concrete columns under cyclic reversed loading, Xi'an University of Arch. \& Tech.(natural science edition) 48(1) (2016).

[93] W.O. Oyawa, N.K. Gathimba, N. Geoffrey, Innovative composite concrete filled plastic tubes in compression, 2015 World Congress on Advances in Structural Engineering and Mechanics (ASEM15), 2015, pp. 1-15.

[94] J.-Y. Wang, Q.-B. Yang, Investigation on compressive behaviors of thermoplastic pipe confined concrete, Construction and Building Materials 35 (2012) 578-585.

[95] N.A. Abdulla, Concrete filled PVC tube: A review, Construction and Building Materials 156 (2017) 321-329.

[96] H. Toutanji, M. Saafi, Durability studies on concrete columns encased in PVC-FRP composite tubes, Composite structures 54(1) (2001) 27-35.

[97] J. Wang, Q. Yang, Experimental study on mechanical properties of concrete confined with plastic pipe, ACI Materials Journal 107(2) (2010) 132.

[98] R. Nowack, O.I. Otto, E.W. Braun, 60 Jahre Erfahrungen mit Rohrleitungen aus weichmacherfreiem Polyvinylchlorid (PVC-U), KRV Nachrichten (1995) $1-95$.

[99] P.K. Gupta, V.K. Verma, Study of concrete-filled unplasticized poly-vinyl chloride tubes in marine environment, Proceedings of the Institution of Mechanical Engineers, Part M: Journal of Engineering for the Maritime Environment 230(2) (2016) 229-240

[100] I. Jakubowicz, N. Yarahmadi, T. Gevert, Effects of accelerated and natural ageing on plasticized polyvinyl chloride (PVC), Polymer degradation and stability 66(3) (1999) 415-421.

[101] A.S. Saadoon, Experimental and Theoretical Investigation of PVC Concrete composite Columns, University of Basrah (2010).

[102] H. Zhang, M.N.S. Hadi, Geogrid-confined pervious geopolymer concrete piles with FRP-PVC-confined concrete core: Concept and behaviour, Construction and Building Materials 211 (2019) 12-25

[103] G. Zong, J. Hao, X. Hao, Y. Fang, Y. Song, H. Wang, R. Ou, Q. Wang, Enhancing the flame retardancy and mechanical properties of veneered wood flour/ 
polyvinyl chloride composites, Polymer Composites 41(3) (2020) 848-857.

[104] H. Toutanji, M. Saafi, Stress-strain behavior of concrete columns confined with hybrid composite materials, Materials and structures 35(6) (2002) 338.

[105] M. Marzouck, K. Sennah, Concrete-filled PVC tubes as compression members, Composite Materials in Concrete Construction: Proceedings of the International Seminar held at the University of Dundee, Scotland, UK on 5-6 September 2002, Thomas Telford Publishing, 2002, pp. 31-37.

[106] F. Yu, D. Niu, Stress-strain model of PVC-FRP confined concrete column subjected to axial compression, Academic Journals, 2010.

[107] Y. Fang, F. Yu, Y. Guan, Z. Wang, C. Feng, D. Li, A model for predicting the stress-strain relation of PVC-CFRP confined concrete stub columns under axial compression, Structures, Elsevier, 2020, pp. 259-270.

[108] S.-F. Jiang, S.-L. Ma, C.-L. Liang, Z.-Q. Wu, Axial Behavior of CFRP-PVCConfined Concrete Stubs, Advanced Science Letters 9(1) (2012) 197-203.

[109] A.M. Mammen, M. Antony, Experimental Study On Frp-Pvc Confined Circular Columns, International Research Journal of Engineering and Technology (IRJET) 4(5) (2017).

[110] Y. Yu, Z. Wu, H. Guan, Experimental Study On The Axial Compression Of GRP-Concrete-PVC Tube Composite Column, IOP Conference Series: Earth and Environmental Science, IOP Publishing, 2019, p. 042013.

[111] H. Toutanji, Design equations for concrete columns confined with hybrid composite materials, Advanced Composite Materials 10(2-3) (2001) 127-138.

[112] A.M. Woldemariam, W.O. Oyawa, T. Nyomboi, The Behavior of Concrete-Filled Single and Double-Skin uPVC Tubular Columns Under Axial Compression Loads, The Open Construction \& Building Technology Journal 13(1) (2019).

[113] F. Hong-bo, Mechanics behavior of FRP-PVC concrete column [j], Low Temperature Architecture Technology 5 (2009).

[114] Y. Qi-bin, New progress on the study of a new type of hybrid columns based on FRP and PVC [J], Journal of Changchun Institute of Technology (Natural Sciences Edition) 1 (2011).

[115] M. Fakharifar, G. Chen, FRP-confined concrete filled PVC tubes: A new design concept for ductile column construction in seismic regions, Construction and Building Materials 130 (2017) 1-10.

[116] F. Yu, G. Xu, D. Niu, A. Cheng, P. Wu, Z. Kong, Experimental study on PVC-CFRP confined concrete columns under low cyclic loading, Construction and Building Materials 177 (2018) 287-302.

[117] M. Bazli, A. Jafari, H. Ashrafi, X.-L. Zhao, Y. Bai, R.S. Raman, Effects of UV radiation, moisture and elevated temperature on mechanical properties of GFRP pultruded profiles, Construction and Building Materials 231 (2020) 117137.
[118] M. Bazli, H. Ashrafi, A.V. Oskouei, Effect of harsh environments on mechanical properties of GFRP pultruded profiles, Composites Part B: Engineering 99 (2016) 203-215

[119] F. Micelli, A. Nanni, Durability of FRP rods for concrete structures, Construction and Building materials 18(7) (2004) 491-503.

[120] D. Lau, Q. Qiu, A. Zhou, C.L. Chow, Long term performance and fire safety aspect of FRP composites used in building structures, Construction and building materials 126 (2016) 573-585.

[121] G. Wu, X. Wang, Z. Wu, Z. Dong, G. Zhang, Durability of basalt fibers and composites in corrosive environments, Journal of Composite Materials 49(7) (2015) 873-887.

[122] M. Bazli, H. Ashrafi, A. Jafari, X.-L. Zhao, R. Raman, Y. Bai, Effect of fibers configuration and thickness on tensile behavior of GFRP laminates exposed to harsh environment, Polymers 11(9) (2019) 1401.

[123] H. Ashrafi, M. Bazli, E.P. Najafabadi, A.V. Oskouei, The effect of mechani$\mathrm{cal}$ and thermal properties of FRP bars on their tensile performance under elevated temperatures, Construction and Building Materials 157 (2017) 1001-1010.

[124] H. Ashrafi, M. Bazli, A. Vatani Oskouei, L. Bazli, Effect of sequential exposure to UV radiation and water vapor condensation and extreme temperatures on the mechanical properties of GFRP bars, Journal of Composites for Construction 22(1) (2018) 04017047.

[125] M. Bazli, H. Ashrafi, A. Jafari, X.-L. Zhao, H. Gholipour, A.V. Oskouei, Effect of thickness and reinforcement configuration on flexural and impact behaviour of GFRP laminates after exposure to elevated temperatures, Composites Part B: Engineering 157 (2019) 76-99.

[126] A.V. Oskouei, M. Bazli, H. Ashrafi, M. Imani, Flexural and web crippling properties of GFRP pultruded profiles subjected to wetting and drying cycles in different sea water conditions, Polymer Testing 69 (2018) 417-430.

[127] A. Jafari, M. Bazli, H. Ashrafi, A.V. Oskouei, S. Azhari, X.-L. Zhao, H. Gholipour, Effect of fibers configuration and thickness on tensile behavior of GFRP laminates subjected to elevated temperatures, Construction and Building Materials 202 (2019) 189-207.

[128] M. Bazli, X.L. Zhao, R.S. Raman, Y. Bai, S. Al-Saadi, Bond strength durability between FRP tubes and seawater sea sand concrete under sea water condition, Asia-Pacific Conference on FRP in Structures 2019, APFIS Conference Series, 2019.

[129] H.A. Toutanji, L. Zhao, G.J. Isaacs, Durability studies on concrete columns confined with advanced fibre composites, International Journal of materials and product technology 28(1-2) (2007) 8-28. 